\title{
Privatlivets fred
}

\section{DANSK KRONIK}

Ved lov nr. 89 af 29. marts 1972 er der gennemf $ø$ rt en revision af bestemmelserne om fredskrænkelser i strfl. kap. 27. Om lovforslaget og straffelovrådets betænkning, se NTfK 1971 p. $246 \mathrm{f}$.

Baggrunden for denne lovrevision mă navnlig søges i de gennem 1960 'erne stadig hyppigere fremsatte $\varnothing$ nsker om en stærkere retlig beskyttelse af privatlivets fred. Under denne problemstilling falder forskellige spørgsmål som straffeloven også hidtil har taget stilling til, dog til dels $i$ en mangelfuld udformning, men også spørgsmål om krænkelsesformer der ikke var kendte eller sjældent forekom, da lovens regler blev forberedt $i$ årene forud for 1930.

Her skal ikke i enkeltheder omtales de ændringer som er foretaget i reglerne om brud på brevhemmeligheden og husfredskrænkelse (se nu strfl. $\S \S 263, \mathrm{nr} .1$ og 2, og 264).

En kriminalisering med videre sigte er sket ved indføjelse af en bestemmelse i strfl. $\S 263$, $\mathrm{nr}$. 3, om straf for den som uberettiget ,ved hjælp af et apparat hemmeligt aflytter eller optager udtalelser fremsat $\mathrm{i}$ enrum, telefonsamtaler eller anden samtale mellem andre eller forhandlinger i lukket møde, som han ikke selv deltager i, eller hvortil han uberettiget har skaffet sig adgang".

Medens denne bestemmelse omfatter aflytning og optagelse ved hjælp af et apparat ikke blot på privat område, men også andre steder (jfr. ordene ,anden samtale mellem andre"), er en ny bestemmelse om fotografering og udspejdning begræenset til sådant område som i bestemmelsen om husfredskrænkelse ( $\$ 264$ ) hidtil har været kaldt og fortsat kaldes „ikke frit tilgængeligt sted“, se § 264 a: „Den, som uberettiget fotograferer personer, der befinder sig på et ikke frit tilgængeligt sted, straffes med b $\phi$ de, hæfte eller fængsel indtil 6 måneder. Det samme gælder den, der ved hjælp af kikkert eller andet apparat uberettiget iagttager sådanne personer". Det fremgår af ordene at strafansvaret også omfatter den der ikke selv befinder sig på det ikke frit tilgængelige sted $\mathrm{i}$ det $\emptyset$ jeblik hvor han fotograferer, bruger kikkert etc.

Til alle de bestemmelser ved hvilke fredskrænkelse på første hånd er gjort strafbar føjes i § $264 \mathrm{c}$ den supplerende bestemmelse at strafansvaret også omfatter ,den, der uden at have medvirket til gerningen skaffer sig eller uberettiget udnytter oplysninger, som er fremkommet ved overtrædelsen ". En videre kreds af personer rammes desuden af en bestemmelse i $\$ 264 \mathrm{~d}$ om ,den, der uberettiget videregiver meddelelser eller billeder vedrørende en andens private forhold eller i øvrigt billeder af den pågældende under omstændigheder, der åbenbart kan forlanges unddraget offentligheden “. Og det tilføjes: „Bestemmelsen finder også anvendelse, hvor meddelelsen eller billedet vedrører en afd $\varnothing d$ person". 
Alle de nævnte forseelser er undergivet privat påtale.

Der er samtidig sket en ændring i reglen i $\S 15$ i ikrafttrædelsesloven til straffeloven om godtg $\phi$ relse for ikke- $\varnothing$ konomisk skade. Sådan godtgørelse har hidtil været betinget af at der forelå en strafbar krænkelse, hvilket bl. a. har medf $\varnothing$ rt at der ikke har kunnet ydes godtgørelse for uagtsom krænkelse af privatlivets fred. Efter den nye affattelse af $\S 15$, stk. 1, kræves det kun at der foreligger en ,retsstridig“ krænkelse af nogens fred, ære eller person i $\varnothing$ vrigt. Godtgørelsen, der som hidtil angår „lidelse, tort, ulempe, lyde og vansir samt forstyrrelse eller $\phi$ delæggelse af stilling og forhold", er gjort obligatorisk. Om udmålingen af godtgørelsen, se nu $\S 15$, stk. 2.

Fra ændringslovens område skal endelig peges på en ny bestemmelse i retsplejelovens $\S 750 \mathrm{c}$ om aflytning under politimæssig efterforskning og en ændret affattelse af konkurrencelovens $\S 11$ om tilegnelse eller videregivelse af erhvervshemmeligheder.

\section{Flykapring}

Ved lov nr. 95 af 29. marts 1972 er der i borgerlig straffelov som $\S 183$ a indf $\phi$ jet $f \varnothing$ lgende bestemmelse om kapring af luftfart $\varnothing \mathrm{j}:$ „Den, som om bord i et luftfartøj ved ulovlig tvang, jfr. $\S 260$, overtager kontrollen over luftfart $\phi$ jet eller griber ind i dettes man $\phi v r e r i n g$, straffes med fængsel indtil 12 år". Bestemmelsen er placeret i strfl. kap. $20 \mathrm{om}$ „almenfarlige handlinger“, som bl. a. omfatter brandstiftelse, sprængning, fremkaldelse af fare for samfærdselsmidler $\mathrm{m}$. v. De strafbare tvangsmidler ved flykapring vil efter henvisningen til strfl. § 260 navnlig være vold, trusel om vold, om betydelig skade på gods eller om frihedsber $\varnothing$ velse. Om retstilstanden f $\varnothing \mathrm{r}$ lovændringen henvises til dommen U 1971.609 (H), hvor en flykapring, som førte til at et polsk passagerfly blev tvunget til at lande i Danmark, henf $\varnothing$ rtes under strfl. $\S 260$ og $\S 184$. Straffen fastsattes til 5 års fængsel. — Den nye $\S 183$ a har samtidig givet anledning til et par ændringer i jurisdiktionsreglerne i strfl. § 8; således er flykapring henlagt under justitsministerens påtale.

\section{Skattesvig og indsmugling}

De i NTfK 1971 p. 248 omtalte forslag om ændring af reglerne om straf for skattesvig, indsmugling $\mathrm{m}$. v. er gennemført i 1971 ved lov nr. 537 af 17. december om ændring af toldloven, lov nr. 539 af 17. december om ændring af skattekontrolloven og lov $\mathrm{nr}$. 550 af 22 . december om ændring af borgerlig straffelov. Strfl. kap. 28 om berigelsesforbrydelser indeholder altså nu i $\S 289$ en bestemmelse om straf af fængsel indtil 4 år for skattesvig og indsmugling af særlig grov karakter. 


\section{Efterforskning $i$ straffesager}

I januar 1968 nedsatte justitsministeriet et udvalg med den opgave at gennemgå reglerne i retsplejelovens 4 . bog, 2. og 3. afsnit, der handler henholdsvis om midler til sagens oplysning (herunder anholdelse og fængsling) og om efterforskning og forundersøgelse. Senere har justitsministeriet også anmodet udvalget om at tage en række andre straffeprocessuelle sp $\phi$ rgsmål op til overvejelse.

Udvalget, hvis formand er landsdommer Povl Hansen, har afgivet en „Betænkning om efterforskning i straffesager m. v.“ (Bet. nr. 622, 1971), som indeholder resultaterne af det indtil nu gennemf $\varnothing$ rte arbejde. I betænkningens f $\varnothing$ rste hovedafsnit om „Efterforskning“ giver udvalget udtryk for det principielle synspunkt, at forunders $\emptyset$ gelse for retten $b \varnothing r$ afskaffes som et særligt processtadium, således at reglerne om straffesagers forberedelse samles om politiets efterforskning med den dertil hørende adgang til at foranledige rettens medvirken med hensyn til beslutninger om fængsling, telefonaflytning, mentalunders $\varnothing$ gelse $\mathrm{m}$. v., afholdelse af indenretsligt forh $\emptyset \mathrm{r}$ og afg $\varnothing \mathrm{relse}$ af tvistigheder under efterforskningen. Udvalgets forslag indebærer ikke dybtgående indgreb i straffeprocessens nuværende struktur, men er en længe forudset - stadfæstelse af en tilstand, der har været præget af et ringe behov for en særlig retslig forunders $\phi$ gelse. Derimod har forslaget givet udvalget anledning til at overveje en mere tidssvarende udformning af reglerne om visse til efterforskningen hørende problemer, bl, a. om forsvarerens stilling.

Betænkningens andet hovedafsnit handler om afh $\phi$ ring af børn og unge som sigtede eller vidner. Spфrgsmålet har allerede ud fra formelle synspunkter trængt til en samlet behandling med henblik på lovændringer, idet de gældende regler — som udvalget med rette fremhæver - er ,,spredte og uoverskuelige og på grund af deres gradvise tilblivelse ikke helt vel koordinerede“. Til dette afsnit i betænkningen knytter sig bilag indeholdende materiale til støtte for udvalgets overvejelse.

Uden for rammen af de mere almindelige straffeprocessuelle spørgsmål indeholder betænkningen i sit tredie hovedafsnit udvalgets overvejelser vedrørende spørgsmålet om undersøgelser mod personer ansat i politiets tjeneste. Et særligt udvalg under justitsministeriet, det såkaldte politiauditørudvalg, havde afgivet betænkning herom i 1968, og justitsministeriet havde derefter anmodet det straffeprocessuelle udvalg om at afgive en udtalelse om nogle af de problemer, der var behandlet $\mathrm{i}$ betænkningen af 1968 .

Det oplyses i betænkningen at udvalgets fortsatte arbejde vedrører de særlige retsmidler under efterforskningen (herunder fængsling) samt reglerne om erstatning for uforskyldt varetægtsfængsling. 


\section{Militier straffelov og retsplejelov}

Forsvarsministeren har i februar 1972 fremsat forslag om ny militær straffelov og retsplejelov til afløsning af de nugældende love fra henholdsvis 1937 og 1919. Forslagene er udarbejdet på grundlag af de overvejelser og forslag der fremkom i det såkaldte „klimaudvalg“s betænkning "Straf og disciplinarmidler. Klageregler" (Bet. nr. 586, 1970). Et yderligere lovforberedende arbejde er blevet udført i en af forsvarsministeriet i juli 1970 nedsat arbejdsgruppe.

\section{De tidsubestemte foranstaltninger}

Medlemmer af partiet Det radikale Venstre har i januar i folketinget fremsat et lovforslag om ophævelse af de delvis tidsubestemte foranstaltninger ungdomsfængsel, arbejdshus og sikkerhedsforvaring. Ved forslagets fremsættelse er bl. a. henvist til at de nævnte foranstaltninger ikke i vor tid adskiller sig væsentligt fra fuldbyrdelsen af almindelig fængselsstraf, ligesom det anføres at det tidsubestemte element påfører de indsatte et betydeligt psykisk pres. De tidsubestemte foranstaltninger strider mod fremherskende humanitetsideer i det danske samfund og afviger fra almindelige retfærdighedsforestillinger. Og de opnåede behandlingsresultater skønnes ikke at retfærdiggøre den relativt ubestemte hensættelsestid. Justitsministeren fremhævede i sin svartale at det også efter hans opfattelse var vigtigt at tage de rejste spørgsmål op til overvejelse. Han henviste til at der ville komme en betænkning fra straffelovrảdet om de strafferetlige særforanstaltninger, og at det måtte anses for ønskeligt at afvente denne betænkning, således at folketinget bl. a. kunne få lejlighed til at drøfte ungdomsfængsel, arbejdshus og sikkerhedsforvaring i sammenhæng med forvaring i medf $\phi r$ af straffelovens $\S 70$, der ikke var omfattet af forslaget af januar 1972. - Det ventes at straffelovrådets betænkning vil foreligge inden den nye folketingssamling begynder i oktober, og at justitsministeren vil fremsætte lovforslag hurtigt derefter.

\section{Forebyggelse af stofmisbrug}

Regeringens kontaktudvalg vedrørende ungdomsnarkomani har $\mathrm{i}$ april 1972 udsendt „Redegørelse III om præevention af stofmisbrug“, udarbejdet af et underudvalg og derefter tiltrådt af kontaktudvalget. I modsætning til de to f $\varnothing$ rste redeg $\phi$ relser $(1969-70)$, der overvejende handlede om behandlingsspørgsmål, beskæftiger denne sig med spørgsmål om forebyggelse af stofmisbrug blandt unge: restriktioner vedrørende euforiserende stoffer, politiets og toldvæsenets funktioner, fritidstilbud, oplysning, ops $\varnothing$ gning af børn og unge der er truede eller skadede af stofmisbrug $\mathrm{m}$. v. Udvalget har ikke begrænset sig til nogle få afg $\phi$ rende fremst $\phi d$ af forebyggende karakter men har, som opgaven vel naturligt stillede sig, lagt vægt på at fremhæve en lang række mere eller mindre specielle punkter hvor et forebyggende arbejde kunne 
tænkes at få betydning, - herunder nogle punkter hvor udvalget selv har forslag eller $\varnothing$ nsker at fremsætte (se udvalgets sammenfattende oversigt i kap. 8). Forebyggelsens vidtspændende problematik har givet udvalget anledning til at overveje om man skulle foreslå en højere grad af centraliseret eller koordineret administrativ virksomhed til gennemførelse af forslagene. Det er udvalgets konklusion at gennemf $\varnothing$ relsen af de konkrete foranstaltninger som hidtil bør ligge hos de enkelte statslige og kommunale myndigheder. Indenrigsministeriet har for sit vedkommende givet udtryk for at man agter at medvirke til en øget koordination.

Det fremhæves $\mathrm{i}$ betænkningen at man ikke i denne omgang har taget stilling til spørgsmål vedrørende unge fra de andre nordiske lande der har taget ophold i københavnske stofmisbrugermiljøer. Disse problemer har bl. a. været drøftet pả et nordisk kontaktmandsm $\varnothing$ de i Oslo i januar 1972.

\section{Foranstaltninger mod advokaters underslæb}

Et af Advokatrådet i 1970 nedsat udvalg har afgivet en „Betænkning om foranstaltninger mod advokaters underslæb" (offentliggjort i Advokatbladet $1972 \mathrm{nr} .5$, p. 57-65). Det anføres at Advokatrådet havde $\varnothing$ nsket at foretage ,en så vidt muligt tilbundsgående undersøgelse af problemerne omkring de stadigt forekommende advokatunderslæb for derved at s $\emptyset$ ge at belyse årsagerne til, at sådanne handlinger begås, at vurdere virkningerne af allerede indf $\varnothing$ rte foranstaltninger og at overveje, om yderligere foranstaltninger må anses for hensigtsmæssige“. På denne baggrund må det siges at være temmelig lidt udvalget har at oplyse om underslæbene og at foreslå med henblik på forebyggelse. Man har haft en oversigt over alle domme i årene 1947-1969 (antallet oplyses ikke), og det fastslås at hovedårsagerne til de kriminelle forhold er sygdom, tab ved udenomsvirksomhed og manglende dygtighed. Udvalget har navnlig overvejet 8 typer af forebyggende foranstaltninger: 1) pligtmæssig revision af advokatregnskaber, 2) pligtmæssig indsendelse af årsregnskaber til advokatmyndighederne, 3) pligtmæssige årlige saldomeddelelser til klienter, 4) udvidet adgang for advokatmyndighederne til at kræve regnskaber indsendt, 5) skærpede regler om indsendelse af klientkontoerklæringer med revisorattest, 6) standardisering af regnskaber, 7) kollektiv sygeforsikring og 8) etablering af et hjælpefond. Der stilles et forslag ad pkt. 5, og det oplyses ad pkt. 8 at der ved legatmidler er stiftet et hjælpefond på $400.000 \mathrm{kr}$. Men iøvrigt stilles ingen positive forslag, bortset fra at man udtrykker sympati for fortsatte overvejelser om visse sp $\varnothing \mathrm{rgsmål}$ om revisionspligt, regnskabsopstilling $\mathrm{m}$. $\mathrm{v}$. og for en $\phi$ get brug af allerede gældende regler om granskning af regnskaber. 


\section{FINSK KRÖNIKA}

Förmögenhetsbrotten utgör en brottsgrupp, som redan länge varit mogen för lagstiftningsåtgärder. Då en totalreform på detta område kommer att låta vänta på sig har regeringen tillställt riksdagen förslag till ändring av speciellt sådana stadganden, som i nuvarande form allmänt ansetts leda till oskälighet.

Strafflagens 28 kapitel skulle erhålla rubriken „Om stöld“ och i dess tre paragrafer skulle ingå bestämmelser angående stöld, grov stöld respektive snatteri. Begreppet stöld har inte närmare definierats, utan man har nöjt sig med en vägledande beskrivning av lydelsen „den som ur annans besittning tillgriper lös egendom...". Påföljden för stöld skulle utgöra fängelse $i$ högst två år eller böter och för snatteri skulle påföljden utgöra enbart böter. För närvarande inrymmer straffsatsen för stöld enbart frihetsstraff och blott i det fall ett tillgrepp med beaktande av det tillgripnas värde och övriga omständigheter vid brottets begående kunnat anses ringa har reglerna om snatteri stått till buds. Det torde ligga i öppen dag att domstolarna prässat räjongen för snatteri långt utöver det lagstiftaren i tiden avsett, och på grund av de klumpiga bestämmelserna angående återfall har domstolarna, för att enligt gällande lag kunna utdöma bötesstraff för t. ex. ett butikssnatteri en återfallsförbrytare gjort sig skyldig till, haft att överösa den förbryllade åtalade med svävande förklaringar om tillgreppets obetydlighet, det tillgripnas futtiga värde etc.

Med dylik list och fintlighet har påföljderna för de okvalificerade tillgreppen i de flesta fall kunnat hållas inom anständighetens ram, men däremot har de styva stadgandena beträffande grov stöld, där minimistraffet utgör sex månader tukthus och påföljden, även då omständigheterna vid begåendet av den grova stölden befinnes vara synnerligen mildrande, dock skall utsättas i form av frihetsstraff, i många fall medfört oskäliga slutresultat. Enligt lagförslaget skulle vid bedömandet huruvida stölden skall betraktas som grov hänsyn tagas till sådana omständigheter som godsets särskilt höga värde eller farlighet, att gärningsmannen försett sig med vapen eller sprängämnen eller att gärningen begåtts av en liga och brottet „i ovannämnda eller övriga fall med beaktande av de omständigheter i sin helhet, vilka föranlett brottet och framgår av detsamma“, bör anses som kvalificerat.

Förenämnda citerade sats har hos oss kommit till användning bl. a. vid ändringen av stadgandena beträffande brott mot kroppslig integritet (1969 misshandel och 1971 sedlighetsbrott) och samma teknik föreslås tillämpad i samband med stadgandena beträffande försnillning, rån och skattebedrägeri. Utan större saknad avstår vi från kvarlevorna av kasuistisk lag $\mathrm{i}$ den form den återfinns i nuvarande stadgande om grov stöld för att bereda plats för smidiga lagregler ofta grupperade (enligt svenskt mönster) i normalfallet flankerat av en 
lindrig och en grov version av gärningen och med påföljderna så bestämda, att de till en del täcker varandra.

Ur lagförslaget kan ytterligare utläsas en strävan att ställa påföljderna för de särskilda förmögenhetsbrotten i relation till den skada gärningarna kan väntas medföra. I överensstämmelse med detta har sanktionerna för t. ex. banala stöldsbrott lindrats, medan däremot straffsatserna för brott i form av försnillning och bedrägeri samt framförallt skattebedrägeri skärpts.

En allmän straffminskningsbestämmelse har efter det bestämmelser angående påföljdseftergift infördes stått på önskelistan. I avsaknad av den förra möjligheten har frestelsen att tumma på reglerna angående påföljdseftergift varit stor. Detta ,allt eller intet"-dilemma föreslås löst genom ett lagförslag innehållande regler om att domstolarna under vissa betingelser finge utsätta lindrigare påföljder än de i lag för ett bestämt brott föreskrivna straffen.

En totalreform av straffrätten skall förberedas av en kommitté, som har att framlägga sitt betänkande på hösten 1973. Kommittén har att draga upp riktlinjerna för de principer, enligt vilka en reviderad lagstiftning på straffrättens område skall uppbyggas, uppgöra en prioritetsordning för de strävanden och värden denna lagstiftningen skall främja och skydda samt taga ställning till de straffrättsliga åtgärder samhället skall kunna trygga sig till. Ytterligare skall kommittén taga ställning till huruvida det vore ändamålsenligt att $i$ en enhetlig strafflag samla de straffbud, som för närvarande återfinnes spridda i särskilda speciallagar.

Vid sidan av kommittén tillsattes även fyra arbetsgrupper för att bistå kommittén vid utarbetandet av sådana straffstadganden, som hänför sig till området för miljöskydd, arbetsrätt, vägtrafiklagstiftning och skatterätt. Förutom det nordiska lagstiftningsarbetet har kommittén att taga speciell hänsyn till lagberedningsarbetet rörande tryckfrihet, intimitets- och konsumtionsskydd samt den militära strafflagen. Ytterligare skall kommittén för att skapa ett nytt straffrättsligt system, som „förverkligar och främjer principerna om jämlikhet och demokrati“, fästa uppmärksamhet vid bl. a. nurådande rättsuppfattning och den inbördes relationen mellan påföljder för brott och överträdelser, undersöka möjligheterna att betrakta juridiska personer som subjekt för brott, utöka målsägandebrottens antal, utveckla reglerna beträffande konfiskation ävensom minska de frihetsberövande påföljdernas antal, utreda möjligheterna att i vissa fall ersätta frihetsstraff med kortvarigt arreststraff samt överhuvudtaget utöka påföljdsalternativen.

Med hänsyn till den korta tid kommittén fått till sitt förfogande och dả kommitténs medlemmar har att vid sidan av sina ordinarie tjänster och uppdrag „på lediga stunder“ utarbeta betänkandet får man synbarligen inte ställa alltför höga krav på resultatet av kommitténs mödor. Det är väl närmast principerna för lagstiftningsarbetets rikt- 
linjer som skall framgå ur betänkandet, men allt vad därutöver kommer bör räknas kommittén till förtjänst.

Dödsstraffet skall slopas även ur den militära strafflagen. I fredstid verkställdes den sista dödsdomen år 1826 och genom en år 1949 given lag avskaffades användningen av dödsstraff i fredstid. Genom en lagändring år 1969 avskaffades dödsstraffet för mord och genom en den 14 januari 1972 given lag om ändring av strafflagen för krigsmakten inskränktes i betydande mån tillämpningsområdet för dödsstraffet. Denna successiva lagstiftningsprocedur har nu nått så långt, att riksdagen med rösterna $140-29$ vid ärandets andra behandling avskaffat dödsstraffet ur hela straffsystemet.

Bostadslösa alkoholister till ett antal om vidpass 3000 finns för närvarande i Helsingfors. Man räknar med att vidpass 250 av dessa inte sett en nykter dag under de senaste åren. I Helsingfors och dess närmaste omgivningar finns omkring 300 vårdplatser. År 1967 öppnades ett nödhärbärge i ett gammalt färglager, men sedan dess har utvecklingen så gott som helt stått stilla. Nära nog en tredjedel av invånarna i nödhärbärget har jobb av något slag, varför en egen nyckel till ett eget rum torde vara den banala lösningen för mångens del. Ett planerat nytt nödhärbärge med 100 tillnyktringsplatser, 100 inkvarteringsplatser och 50 dagklubbsplatser skulle komma att kosta 2,5 miljoner mark. Beloppet verkar futtigt i relation till kongresshusets 40 miljoner, stadsteaterns 32 miljoner och stadshusets sanering för 29 miljoner mark.

Christer Kuhlefelt. 


\section{SVENSK KRÖNIKA}

\section{Lagstiftning}

I början av 1972 gjordes vissa ändringar i åklagarinstruktionen och polisinstruktionen samt utfärdades ett cirkulär till polismyndigheterna om rapporteftergift för vissa snatteribrott (Svensk författningssamling 1972:23-25).

Ändringen i åklagarinstruktionen innebär att lägre åklagare ges generell behörighet att besluta att inte tala å de mindre förmögenhetsbrotten, dvs. snatteri, bedrägligt beteende och undandräkt, samt att utfärda strafförlägganden för samma slags brott. Genom ändringen i polisinstruktionen ges polisman son är förundersökningsledare möjlighet att lämna rapporteftergift för vissa snatteribrott. De nya bestämmelserna syftar till att begränsa det straffrättsliga ingripandet vid de mindre förmögenhetsbrotten. Främst avses de $\mathrm{s} k$ butikssnatterierna, t ex tillgrepp i snabbköpsbutiker och varuhus med självbetjäning. Ändringarna i polis- och åklagarinstruktionerna, som trädde i kraft den 1 april 1972, innebär ett genomförande av några av huvudprinciperna $\mathrm{i}$ det av 1968 års brottmålsutredning avgivna betänkandet "Snatteri“ (SOU 1971:10, se NTfK 1971 s 260).

\section{Kommittéer}

Kommittén för anstaltsbehandling inom kriminalvården har under hösten 1971 avslutat sitt arbete och lagt fram betänkandet „Kriminalvård å anstalt". (SOU 1971:74, direktiven se NTfK 1967 s 325). Kommitténs ordförande, justitierådet Ingrid Gärde Widemar, redogjorde för huvuddragen i kommittéförslaget vid Svenska kriminalistföreningens årsmöte 1970. Hennes anförande finns intaget i NTfK $1971 \mathrm{~s}$ $265-78$.

I början av 1972 överlämnade ämbetsansvarskommittén slutbetänkandet „Ämbetsansvaret II“ (SOU 1972:1). Kommittén har tidigare i ett principbetänkande „Ämbetsansvaret“ (SOU 1969:20) redovisat de grundläggande principer som kommittén ansåg sig böra utgå ifrån vid skapandet av ett sanktionssystem för offentliga funktionärer.

I slutbetänkandet föreslår kommittén ett sanktionssystem som kan tillämpas inom alla delar av det offentliga anställningsförhållandet. Det föreslås vidare att de regler om absoluta avtalsförbud i tjänstemannalagstiftningen vilka betingas av nuvarande bestämmelser om ämbetsansvar ersätts av regler enligt vilka hela det offentliga anställningsförhållandet anses som avtalsgrundat. Avtalsbestämmelser som inskränker den bestämmanderätt som arbetsgivaren ensam har skall dock anses ogiltiga. Med en sådan privaträttslig grundsyn på det offentliga anställningsförhållandet blir varje tjänsteförseelse att se som ett avtalsbrott. För dessa avtalsbrott bör, liksom för avtalsbrott inom privata anställningsförhållanden, i första hand tillämpas de sanktionsmedel som erbjuds inom privaträtten. 
Straffrättsligt ansvar bör dock enligt kommittén finnas i vissa fall och främst inriktas på oriktig utövning av offentlig myndighet. Kommittén föreslår sålunda att det straffbara området skall omfatta missbruk av offentlig myndighet - i oaktsamhetsfall betecknat som vårdslöshet i myndighetsutövning - samt mutbrott och brott mot tystnadsplikt.

Straffansvar för vanliga tjänstefel föreslås således bli avskaffat och ersätts i kommittéförslaget med ett utomstraffrättsligt ansvar av i huvudsak samma natur som i privat tjänst. Det utomstraffrättsliga sanktionssystemet föreslås bli reglerat $i$ en särskild lag om disciplinansvar i offentlig tjänst. I lagen upptas två disciplinpåföljder, varning och en ekonomisk sanktion, penningplikt. För vissa arbetstagargrupper kommer det dock bli möjligt att utforma disciplinansvaret genom avtal.

Kommittén föreslår också att de särskilda ämbetsstraffen avsättning och suspension avskaffas. I stället skall arbetstagaren kunna avskedas på vissa i disciplinlagen angivna grunder.

I processuellt hänseende föreslås att tvister om offentliga anställningsavtal, däribland tvister om påföljder för avtalsbrott, skall prövas av arbetsdomstolen, om tjänsteavtalet regleras av kollektivavtal, och annars av allmän domstol. Enligt kommittéförslaget skall disciplinansvaret inte omfatta vissa funktionärsgrupper, nämligen statsråd, justitieråd, regeringsråd, riksdagens ombudsmän (JO), justitiekanslern (JK) samt ledamöter av beslutande statliga eller kommunala församlingar. För dessa grupper föreslås vissa nya regler.

Även frågan om JO:s och JK:s tillsyn över offentliga funktionärer har behandlats av kommittén. Enligt förslaget utsträcks tillsynen till bl a arbetstagare i vissa samhällsägda företag. Den föreslagna reformen av ämbetsansvaret föranleder också vissa ändringar i brottsbalkens bestämmelser om brott mot offentlig verksamhet.

Under hösten 1971 har en särskild sakkunnig tillkallats för att göra en översyn av brottsbalkens bestämmelser om sedlighetsbrott. Enligt direktiven bör brottsbalkens kapitel om sedlighetsbrott (6 kap.) ses över i sin helhet. 6 kap. brottsbalken innehåller bl a bestämmelser om våldtäkt, otukt med barn, otukt med ungdom, otukt med avkomling och otukt med syskon dvs $\mathrm{s} k$ incestbrott, koppleri och förförelse av ungdom. När det gäller otukt med barn, går skyddsgränsen i gällande rätt vid 15 år och straffbestämmelsen avser både heterosexuella och homosexuella handlingar. I fråga om otukt med ungdom över 15 år gäller olika skyddsgränser för heterosexuellt och homosexuellt könsumgänge. Ungdom mellan 15 och 18 år har ett straffskydd mot heterosexuellt könsumgänge, om gärningsmannen utnyttjar den unges beroendeställning. Mot homosexuellt könsumgänge med ungdom finns ett absolut skydd för unga under 18 år, i de fall där gärningsmannen själv har fyllt 18 år. Ungdom som inte fyllt 20 år har vidare samma 
villkorliga straffskydd mot homosexuellt könsumgänge i beroendeförhållande som ges ungdom mellan 15 och 18 år mot heterosexuella handlingar. Högre gräns för straffskydd mot homosexuella handlingar än mot heterosexuella gäller också enligt straffbestämmelsen om förförelse av ungdom som syftar till att skydda yngre åldersklasser från att dragas in i prostitutionen.

I direktiven anges särskilt att åldersgränserna vid homosexuellt könsumgänge bör utredas. Den sakkunnige har också fått i uppdrag att undersöka om den nuvarande kriminaliseringen av incest bör upprätthållas i full utsträckning. Bland de frågor som särskilt bör studeras anges i direktiven även strafflatituderna för koppleri. Det har nämligen ifrågasatts, om det är rimligt att minimistraffet för grovt koppleri är så högt som fängelse i två år.

Ytterligare en kommitté, som har intresse i det här sammanhanget, har tillsatts under hösten 1971, nämligen kriminalvårdsberedningen. Denna kommitté har fått i uppdrag att samordna, planera och prioritera reformverksamheten inom kriminalvården. Enligt direktiven skall kriminalvårdsberedningen göra upp en plan för det fortsatta reformarbetet. Planeringen bör i första hand ge underlag för ställningstaganden till aktuella reform- och resursbehov inom kriminalvården. Planeringsarbetet bör också sättas in i ett mera långsiktigt perspektiv på kriminalvårdens målsättning och innehåll. Beredningen skall också beakta socialvårdens roll i sammanhanget. I nu angivet syfte bör beredningen gå igenom de utredningsförslag som finns inom kriminalvårdens område och bedöma angelägenhetsgraden av aktualiserade reformer. Utredningsarbetet bör enligt direktiven bedrivas i sådan takt att resultatet av beredningens arbete kan redovisas under första halvåret 1972. 